\title{
Populists in Power: From Municipalities to (European) Parliament, The case of the Italian Five Star Movement
}

\author{
Maria Elisabetta Lanzone ${ }^{1} \cdot$ Mara Morini $^{1}$
}

Received: 4 April 2017/Accepted: 2 June 2017/Published online: 29 June 2017

(C) Fudan University and Springer Nature Singapore Pte Ltd. 2017

\begin{abstract}
The article focuses on the strategic evolution of the Italian Five Star Movement (Movimento 5 Stelle-M5S). The party was born in 2009 as a local and civic experience and it represents a new example of populism characterized by unprecedented traits. In 2010 the M5S obtained its first representatives during regional elections and in 2012 it achieved its first Major in a big town (Parma, in the heart of Italy). This path from the "people" to the political institutions has been completed between 2013 and 2014 with entry into National and European Parliament. The same process caused a lot of changes in party strategies and a strong debate inside the party in regards to its organisation and structure. The local case of Parma will work as an example of "overpromising populism" accused by the central office of a compromise-collusion with the "old" power. An analysis of national and sub-national context will serve as a verification of the idea that power participation leads to "moderation" of populists. In the final section we will hazard some hypothesis about the future of the party and its possible "government role" in a more comparative perspective.
\end{abstract}

Keywords Populism - Power · Institutions - Italian politics · Five Star Movement

Maria Elisabetta Lanzone

mariaelisabetta.lanzone@edu.unige.it

Mara Morini

mara.morini@unige.it

1 Department of Political Sciences - DISPO, University of Genova, Genoa 16125, Italy 


\section{Introduction}

Populism often manifests itself as a protest answer towards current political institutions. In particular, populist phenomena (parties and movements) are classified as anti-establishment actors in the political arena (Mudde 1996, 2000). In this context, populist organisations struggle to establish and to institutionalize themselves. According to Mény and Surel $(2000,2001,2002)$ the reason of this failure is simple: populism often advantages itself with its overpromising purposes. So, when it arrived to take the power "or it maintains its promises and it is consequentially bound to a failure or it reviews its electoral intents in the hope that its voters will have short memories". In fact, populism, when it is able to undermine the old elites, in the name of a certain popular sovereignty, it is quickly obligated to legitimate the expertise and the professional ability, risking a swift failure or a compromise-collusion with the mainstream politicians.

Under this framework, this article focuses on the strategic evolution of the Italian Five Star Movement (Movimento 5 Stelle-M5S). The party was born in 2009 as a local and civic political experience: it represents a new example of populism characterized by unprecedented traits (Lanzone 2014, 2015). The M5S obtained its first representatives (seats) during regional elections in 2010 and in 2012 it achieved its first Major in a big town (Parma, Emilia-Romagna). This path from the "people" (the protest) to the political institutions has been completed between 2013 and 2014 with entry into National (Chamber of Deputies and Senate) and European Parliament. The same process of institutionalisation caused a lot of consequences and changes in party strategies and a strong debate inside the party in regards to its organisation (structure). In particular, are the relationships between leadership, membership and public office causing ruptures and division at national and/or at sub-national level.

Considering this specific case, we propose a comparison between the original project launched by the party leader/founder (Beppe Grillo) in 2009 and the current party political agenda. After this brief introduction (first section), in the following section (the second) we will describe the main reasons for considering the M5S an example of "new populism" (Lanzone 2017) and we will underline the peculiarities of this case, taking into account the most important schemes in populist studies. In the third section we will proceed with the analysis of five crucial phases in party development with a description of the institutional path completed by the party from 2005 to 2017. In the fourth paragraph we will use the local case of Parma (according to an original field research) as an example (the first and the most controversial) of "overpromising populism" (Mény and Surel 2000) accused by the central office of a compromise-collusion with the "old" power and the elites. An analysis of national and sub-national context (fifth section) will serve as a verification of the idea that power participation leads to "moderation" of populists (Albertazzi and McDonnell 2015). In the final section (the sixth) of our article we will hazard some hypothesis about the future of the M5S and its possible "government role" in a more general (internal and external variables) and in a comparative perspective. 


\section{Theoretical Background: The Rise of the Italian Five Star Movement as a Populist Party}

The Italian Five Star Movement represents the most important novelty in the national political landscape since 1990s (Bordignon et al. 2015). It was founded in 2009 by the comedian Beppe Grillo and in 2013 general elections it became the largest single party in the lower house, obtaining the $25.6 \%$ of the votes. Not even Forza Italia, in the 1994, earned similar results: on that occasion, Berlusconi's party stopped at $21 \%$ of electoral approval. Precisely in the same period a new vacuum was created by the decline of the "Berlusconian era": the vast majority of the existing parties were confronted with a new type of crisis and they attempted to reorganize themselves. From this breakable framework emerged a new political organization, just the M5S, marked by a strong protest purpose.

Literature nowadays accepts a general definition of the M5S as an example of anti-establishment populism or a "web-populism" (Corbetta 2013; Tarchi 2014; Lanzone 2015). However, there is no consensus over conceptions of the people contained in its political project. What kind of populist claim the party proposes? What is moreover the nature of the antagonistic relationship contained in the M5S populist message?

According to the notorious scheme proposed by Mény and Surel (2001: 85), there are three conditions that historically would aid the emergence of populism: a progressive weakening of the traditional mediation apparatus (the political parties) around which the representative democracy was structured, the continuous growth of power personalization with the predominance of "personal parties" (Calise 2010) and the development of media's influence. So, under these circumstances, the protest vote for the M5S appears as a new populist answer to the citizens' needs of renewal of the political class. However, the party's characteristics show some contradictory elements that distinguish this case from other examples of European and Italian populism. At first sight, the party does not represent a typical case of "thick" populism such as the French FN (Ivaldi et al. 2017). Certainly in the M5S political project it is possible to retrace right away a strong anti-system nature. Also, the party proposes a populist message as a political strategy. More controversial appears the analysis of populism as an ideology and in particular the identification of the three conceptions of the people (political; cultural and economic).

With its effective slogan "the parties are dead" and with the statement "It is necessary to bring back the country to the people's will", Grillo's party resolutely declares its populist purpose (in a political sense) and its distrust of traditional parties. ${ }^{1}$ In addition to this "war" against the parties, the M5S also emphasizes its general opposition to the traditional media, that they are responsible for and 'abettors' of politicians' scandals and their corruption. So there is no distinction between party power and old media power. The opposition to the traditional media is part of a wider project of the elite's denigration. So in the M5S's populist claim it is possible to retrace a strong and broad appeal to the sovereign people, with an

\footnotetext{
${ }^{1}$ See Grillo (http://www.beppegrillo.it/2011/11/i_partiti_sono_morti.html, 2 November 2011. Last seen: 31 May 2017).
} 
opposition towards the political class (political elite) in particular and traditional political institutions in general. Instead, this party maintains a slightly ambiguous position with regard to the class-people claim (social and economic populism), and in its original project the cultural (identity) claim is totally absent (Lanzone 2015). ${ }^{2}$ So a strong predominance of its first claim of standing for the sovereign people emerges in its analysis of its conceptions of the people. This peculiarity probably detaches this example from other cases of contemporary populism: in fact, several important populist parties have included all three people conceptions in their projects (such as the Northern League that became a constant presence in the national party system and the oldest party in the national Parliament, too).

This specific nature of the Five Star Movement probably represents a weakness for the party and probably an example of post-ideological populism, too (Lanzone 2017). In fact, the global political project proposed by the Five Stars took advantage of a strong socio-political crisis, and protest voting has been one of the main reasons for them mobilizing a large section of the electorate (those 'disappointed' by current politics) with no clear ideological tendencies. ${ }^{3}$ All these peculiarities and these controversial aspects are able to produce a lot of consequences of the global project proposed by the M5S. It leads us to consider (in the next section) the main phases in party development to better understand changes, adaptations and future divisions have occurred inside the party organisation.

\section{From Protest to Power: The M5S in Representative Institutions}

To better analyse the process from protest to power (institutions) completed by the M5S we will consider five phases in party development. The same process started from a local level and arrived to sub-national level (European Parliament). This path (from local to national/sub-national) produced a lot of consequences in party organisation (Lanzone 2014, 2015).

The political project proposed by the Italian comedian Beppe Grillo born in 2005 thanks to its personal blog. ${ }^{4}$ The same blog was able to collect different needs and demands of protest from "common citizens". It is possible to consider this first step (2005-2009) as a pre-institution phase, a sort of "movement phase" also characterized by the launch of the online platform Meet up that originated the local branches of the future party (Lanzone 2015: 87).

The second phase (2009-2010) is the founding phase and began in 2009 when Grillo decided to propose a national party with a logo and to present candidates for regional and local elections. A third phase (2010-2013) started in 2010 just with the regional lists in Piedmont and Emilia-Romagna. Between 2010 and 2012 the M5S

\footnotetext{
2 Today, especially after 2014 EU-elections there is a debate (media and academic) regarding the party placement towards some divisive problems such as immigrations and national sovereignty. See Lanzone (2017).

3 There is some data about the M5S voters. See, for example: http://www.repubblica.it/politica/2017/06/ 03/news/giovani_e_operai_ecco_i_nuovi_elettori_del_m5s_e_al_sud_cresce_il_consenso-167088062/ (last seen: 31 May 2017).

${ }^{4}$ Blog http://www.beppegrillo.it (last seen: 31 May 2017).
} 
has continued to participate in local elections: in particular in 2012 it obtained first important results with the elections of four mayors. At the end of 2013 (December) the party leader Grillo decided to participate in national elections, too. He proposed online primaries to select candidates for parliament (Chamber of Deputies and Senate). In the same occasion for the M5S the fourth phase arrived (national phase 2013-2014) with a high number of representatives in national parliament (109 in the Chamber and 54 in Senate). In 2014 the party decided to run also for European elections and it obtained 17 seats. So in the same period for the party started a new phase (the fifth) with a lot of changes and challenges at national and sub-national level. The same phase (2014-2017) can be interpreted as an adaption phase: in fact, the party is now able to be part of institutions at different levels.

Table 1 shows the role of the M5S in representative institutions. In particular, it underlines the presence of the party in regional institutions between 2010 and 2016. First representatives arrived in 2010 in two Italian regions (Piedmont and Emilia) where the new party obtained two seats per region. An important aspect is the current distribution of regional councillors: actually the M5S is part of 18 Regional

Table 1 The M5S in representative institutions, regional councillors (2010-2016)

\begin{tabular}{|c|c|c|c|c|c|c|c|c|}
\hline Regions/years & 2010 & 2011 & 2012 & 2013 & 2014 & 2015 & 2016 & Tot/reg \\
\hline Abruzzo & N/A & N/A & N/A & N/A & 6 & N/A & N/A & 6 \\
\hline Basilicata & 0 & N/A & N/A & 2 & 0 & N/A & N/A & 2 \\
\hline Calabria & 0 & N/A & N/A & N/A & 0 & N/A & N/A & 0 \\
\hline Campania & 0 & N/A & N/A & N/A & N/A & 7 & N/A & 7 \\
\hline Emilia-Romagna & 2 & N/A & N/A & N/A & 5 & 0 & N/A & 7 \\
\hline Friuli-V.G. & N/A & N/A & N/A & 5 & N/A & N/A & N/A & 5 \\
\hline Lazio & N/A & N/A & N/A & 7 & N/A & N/A & N/A & 7 \\
\hline Ligury & N/A & N/A & N/A & N/A & N/A & 6 & N/A & 6 \\
\hline Lombardy & 0 & N/A & N/A & 9 & N/A & N/A & N/A & 9 \\
\hline Marche & N/A & N/A & N/A & N/A & N/A & 5 & N/A & 5 \\
\hline Molise & N/A & 0 & N/A & 2 & N/A & N/A & N/A & 2 \\
\hline Piedmont & 2 & N/A & N/A & N/A & 8 & N/A & N/A & 10 \\
\hline Puglia & N/A & N/A & N/A & N/A & N/A & 8 & N/A & 8 \\
\hline Sardinia & N/A & N/A & N/A & N/A & N/A & N/A & N/A & Never \\
\hline Sicily & N/A & N/A & 15 & N/A & N/A & N/A & N/A & 15 \\
\hline Tuscany & N/A & N/A & N/A & N/A & N/A & 5 & N/A & 5 \\
\hline Trentino-A.A. & N/A & N/A & N/A & 2 & N/A & N/A & N/A & 2 \\
\hline Umbria & N/A & N/A & N/A & N/A & N/A & 2 & N/A & 2 \\
\hline Aosta Valley & N/A & N/A & N/A & 2 & N/A & N/A & N/A & 2 \\
\hline Veneto & N/A & N/A & N/A & N/A & N/A & 5 & N/A & 5 \\
\hline Tot. reg. councillors M5S & 4 & 0 & 15 & 29 & 19 & 38 & & 105 \\
\hline
\end{tabular}

Source own elaboration. Thanks to Dario Quattromani (University of Roma 3) for some data 
Councils. Only in Calabria and Sardinia there are no representatives from the Five Stars lists. In the second case (Sardinia) the party never presented candidates in regional elections.

Table 2 underlines the party local rootedness and it focuses the attention on municipal councillors, again in the period between 2010 and 2016. Nowadays the M5S is part of local institutions in all Italian Regions. The most important public office remains in Piedmont and Emilia-Romagna, followed by Lombardy and Tuscany. In the South of Italy the electoral success of the party arrived a little later. However, today the M5S is able to complete its process of entry in representative institutions. The same process is really finalized between 2013 and 2014 when the party arrived at national and sub-national levels (Italian and European Parliament).

This fast enough path from protest movement to representative political force produced a lot of changes in party organisation. In particular, in some cases (we will analyse in following sections) representatives are able to create internal divisions and to reduce the initial populist purposes. Another important consequence we will

Table 2 The M5S in representative institutions, municipal councillors and mayors (2010-2016)

\begin{tabular}{|c|c|c|c|c|c|c|c|c|}
\hline Regions/years & 2010 & 2011 & 2012 & 2013 & 2014 & 2015 & 2016 & Tot/reg \\
\hline Abruzzo & 0 & 0 & 2 & 0 & 14 & 2 & 11 & 29 \\
\hline Basilicata & 0 & 0 & 0 & 1 & 8 & 6 & 12 & 27 \\
\hline Calabria & 0 & 0 & 0 & 1 & 5 & 0 & 2 & 8 \\
\hline Campania & 0 & 0 & 1 & 0 & 3 & 37 & 17 & 58 \\
\hline Emilia-Romagna & 1 & 14 & 33 & 10 & 191 & 3 & 28 & 280 \\
\hline Friuli-V.G. & 0 & 2 & 3 & 6 & 9 & 0 & 9 & 29 \\
\hline Lazio & 0 & 1 & 1 & 23 & 39 & 3 & 98 & 165 \\
\hline Ligury & 0 & 1 & 20 & 7 & 16 & 0 & 8 & 52 \\
\hline Lombardy & 3 & 8 & 24 & 12 & 52 & 37 & 29 & 165 \\
\hline Marche & 0 & 1 & 7 & 6 & 48 & 9 & 28 & 99 \\
\hline Molise & 0 & 0 & 0 & 0 & 3 & 0 & 0 & 3 \\
\hline Piedmont & 0 & 11 & 24 & 3 & 82 & 23 & 64 & 207 \\
\hline Puglia & 0 & 0 & 0 & 1 & 1 & 16 & 40 & 58 \\
\hline Sardinia & 0 & 1 & 2 & 16 & 4 & 23 & 34 & 80 \\
\hline Sicily & 0 & 0 & 0 & 32 & 24 & 50 & 45 & 151 \\
\hline Tuscany & 0 & 5 & 11 & 14 & 133 & 4 & 16 & 183 \\
\hline Trentino-A.A. & 2 & 0 & 0 & 0 & 3 & 22 & 6 & 33 \\
\hline Umbria & 0 & 0 & 0 & 3 & 23 & 0 & 3 & 29 \\
\hline Aosta Valley & 0 & 0 & 0 & 0 & 0 & 2 & 0 & 2 \\
\hline Veneto & 1 & 9 & 49 & 19 & 49 & 9 & 41 & 177 \\
\hline M5S councillors & 7 & 53 & 177 & 154 & 707 & 246 & 491 & 1835 \\
\hline M5S mayors & 0 & 0 & 4 & 3 & 4 & 7 & 22 & 40 \\
\hline
\end{tabular}

Source own elaboration, thanks to Dario Quattromani (University of Roma 3) for some data related to 2015-2016 
consider in next sections is the controversial relationship between different levels. Today the party maintains a lot of organisational problems caused by the internal relations between the three faces (party on the ground/party in public office and party in central office). Additionally, the party in central office nowadays consists of different levels (local/regional/national/sub-national) with heterogeneous traits and less internal structure. These aspects will be discussed in the next sections and in the conclusions to evaluate the future of the party inside the Italian political system and the European landscape, too.

\section{M5S in Local Office: The Case of Parma}

The Five Star Movement, characterized by the Web 2.0, had to face the mobilization in local communities to also compete in administrative elections in 2008 and 2009. This meant to move from an online to an offline political participation and activism. Thanks to the people's interaction in his blog some lists of candidates named "friends of Beppe Grillo" were created with candidates in 75 municipalities, achieving its highest electoral rank of $9.5 \%$ in Bologna local Council. Beppe Grillo's strategy was to perform monologues in theatres, sport centres, city squares, putting much emphasis and rhetoric on the level of the Italian political and economic scandals that allowed him to become the best representative of the general mistrust, apathy, anger and anti-establishment feelings spread throughout the country (Bordignon and Ceccarini 2013: 427-429).

There is no doubt that the process of personalization of politics and the "new media" strongly influenced the rise of personal parties in the Italian electoral campaigns of the 2000s. In such a context Grillo's party was built on the dual pillars of mistrust of traditional politics and honesty of its members and, most importantly, in the crisis of political legitimacy of traditional parties M5S was able to cover the void.

The local elections held in $2012^{5}$ represented the turning point in the political and electoral success of the M5S due to the need to field local candidates, and gather voters' preferences. It was one of the main challenges to face for a new party in 154 municipalities with over 15,000 inhabitants, called to the polls for majors and councillors, especially concentrated in the centre-north of Italy.

What it is important to underline is that the local elections demonstrated the M5S transformed itself from a movement of protest to a political force aiming to govern local communities. The first turnout of these elections placed more than 150 representatives sitting on local councils and, for the first time, the M5S was able to

\footnotetext{
5 An important change in the local electoral law occurred in 2012 in the municipalities with over 5000 inhabitants, where voters have the possibility to use a "gender preference" (one for a male candidate and the second for a female on) to establish gender balances. Most interesting was the introduction of the so called 'double gender preference' allowing the voter to express two preferences (rather than one as foreseen by the previous legislation) provided that the preferences concern candidates of different sex; if not, the second preference is annulled.
} 
get four mayors elected. ${ }^{6}$ Among them, Federico Pizzarotti became unexpectedly mayor of the biggest city involved in this electoral cycle with more than 177,000 inhabitants.

But who is this "boy of the M5S" able to win this electoral competition against traditional parties? In 2012 Pizzarotti was 39-years-old, married and worked in a bank as Project Manager of the area of Information Technology. He was also consultant for financing institutes and in his spare time he played free-climbing and judo. Pizzarotti has always stressed the idea that a mayor is a Project Manager, the front man, able to coordinate a team to solve citizens' needs and problems (Pizzarotti 2016: 48-49).

In 2008 he became a member of the "Parma Meet Up", the local branch of the M5S, where he started to be an activist and, afterwards, was a candidate in the 2010 elections in the regional Emilia-Romagna council. In his biography (Pizzarotti 2016: 23) he wrote that he wanted to bring direct democracy in Parma, i.e., an empirical experiment that was, at first, strongly supported by Beppe Grillo who went to Parma during the local electoral campaign, to have a political speech in a square where many people participated.

The core of Grillo's political communication was on environmental issues concerning the creation of an incinerator located in the famous "Food of Valley" and, consequently, Grillo attacked the local "caste" (centre left and right) that took this decision against the will and people's health.

The other political forces, especially the local branch of the Democratic Party (Partito Democratico-PD), underestimated the importance of this issue and did not expect that an "unknown boy" with no particular local party penetration and organizational structure could achieve such an important electoral affirmation. Moreover, the PD held in local primaries to select the candidate in January 29th and the winner was Vincenzo Bernazzoli who was in charge as the President of the Parma District (Provincia), supported by the left wing within the party. The centre right was not cohesive and political scandals made by the previous administration, led by the mayor, Pietro Vignali, negatively affected the electorate (Morini and Fiorini 2013: 158).

As far as the political scandals in Parma in 2011 the so called "Green Money" investigation led to the arrest of 11 people close to the Mayor, Pietro Vignali, and members of the Environmental Department of the municipality and the Head of municipal police for corruption and extortion.

As Table 3 clearly shows this electoral competition was highly fragmented with 10 lists and only 4 of them reaching more than $10 \%$ of votes. But what it is surprising looking at the data is the change of percentage of votes between the first and second round where Pizzarotti (M5S) passed from a 19-60\%. Parma is the first big city where the Five Star Movement presented its list. The same political force

\footnotetext{
6 The local electoral law established that neither sex could represent more than two-thirds of a party's list of candidates for a municipal council election while in municipalities with up to fifteen thousand inhabitants, the maximum quota for either sex was set at three quarters. As a matter of fact this mechanism allowed a given minimum number of female candidates, but unlike quota systems based on reservation of seats, did not ensure that a minimum number of females would be elected.
} 
Table 3 Electoral results in Parma (2012)

\begin{tabular}{lll}
\hline & First round & Second round \\
\hline Voters: 142,183 & $91.785(64.55 \%)$ & $86,990(61.18 \%)$ \\
Pizzarotti Federico & $17,103(19.47 \%)$ & $51,235(60.23 \%)$ \\
Movimento 5 Stelle (M5S) & $13,817(19.90)$ & $33,837(39.7 \%)$ \\
Bernazzoli Vincenzo & $34,433(39.21 \%)$ & \\
Democratic Party (PD) & $17,472(25.16 \%)$ & \\
Partito dei Comunisti Italiani & $4059(5.84 \%)$ & \\
Altra Politica & $3449(4.97 \%)$ & \\
Italy of Values (Di Pietro's list) & $2032(2.93 \%)$ & \\
Parma che cambia (Vendola's list) & $1815(2.61 \%)$ & \\
Parma Progressista/Socialista/Laica & $1065(1.53 \%)$ & \\
Pensionati & $121(0.17 \%)$ & \\
Ubaldi Elvio & $14,366(16.36 \%)$ & \\
Union of Centre & $4147(5.97 \%)$ & \\
Civiltà Parmigiana & $3890(5.60 \%)$ & \\
Parma Moderata, Libera, Solidale & $1405(2.02 \%)$ & \\
Ghiretti Roberto & $8873(10.10 \%)$ & \\
Parma Unita & $5944(8.56 \%)$ & \\
Roberti Roberta & $4504(5.13 \%)$ & \\
Parma Bene Comune & $1661(2.39 \%)$ & \\
Partito della Rifondazione Comunista & $1290(1.86 \%)$ & \\
Buzzi Paolo & $4209(4.79 \%)$ & \\
People of Freedom (PDL) & $3275(4.72 \%)$ & \\
Cantiere Popolare & $418(0.6 \%)$ & \\
Zanardi Andrea & $2375(2.7 \%)$ & \\
Northern League & $2064(2.97 \%)$ & \\
Bocchi Priamo & $1204(1.37 \%)$ & \\
La Destra & $954(1.37 \%)$ & \\
Bonvicini Walli & $380(0.43 \%)$ & \\
Buongiorno Italia! & $265(0.38 \%)$ & \\
Spaggiari Liliana & $380(0.4 \%)$ & \\
Partito Comunista dei Lavoratori & $302(0.4 \%)$ & \\
Candidates (total) & 87.827 & \\
Party Lists & & \\
\hline Source own & & \\
& & \\
& & \\
& &
\end{tabular}

Source own elaboration on official electoral data

has presented itself as a valid alternative, campaigning on a platform of transparency, change and popular participation in decision-making. ${ }^{7}$

Moreover, Pizzarotti stressed that Parma was the starting place for something new: bicycles replaces chauffeured cars, cutting salary of the Mayor and trimmed

\footnotetext{
${ }^{7}$ Nevertheless the most crucial issue was to stop the construction of the local incinerator. They also promised to reduce the city budget debit raising taxes.
} 
the salary of the employees; council meetings can also be viewed online; they use Facebook and Twitter (Incerti and Pizzarotti 2012).

The third list led by Elvio Ubaldi, who was major in the 1998 and 2002, did not compete in the second round as the centre left expected. So, most of the centre right voters and Ubaldi's supporters turned their preferences towards Pizzarotti to avoid centre left win. ${ }^{8}$ At local level, especially in Parma, the M5S was the main competitor of the PD while the centre right was fragmented and unable to create a cohesive electoral coalition.

Pizzarotti recognized that he would not probably have won in Parma without the political scandals of the previous administrations, but he also said that they were able to take advantage of it and attract citizens' mistrust towards the local authorities and traditional parties. He also underlined the fact that for his electoral campaign spent only $6000 €$ thanks to volunteers' donation in comparison with the more expensive one by Bernazzoli's candidate.

In his autobiographic book he describes his political adventure as a "normal revolution" taking place in a political national landscape "after Berlusconi's government" and with a centre left coalition in search of a united reformist platform. In this political scenario (2010-2012) the M5S arose as an anti-political movement stressing the idea of direct democracy implemented through the Grillo's blog. Some months after the Pizzarotti's electoral success, the M5S competed for the national vote challenging traditional parties and becoming a potential threat.

As a matter of fact, the last 20 years of the history of Italian politics faced the emergence of personal parties, the degree of abstention increased, especially at local level, and a new record in the electoral volatility took place in the parliamentary 2013 election where the new Beppe Grillo's party, ${ }^{9}$ called Five Star Movement, ${ }^{10}$ got $25.6 \%$ of votes (109 deputies and 54 senators).

So, Italy has become a laboratory for a new strain of European populism, in which a next-generation political party, born and bred on the Internet, is less interested in ideology or the standard models of left versus right in using the web as a platform and weapon of anti-establishment anger.

\section{Institutionalization and the Future of the M5S}

In such institutional background - national and local- the role of voting preferences among political parties is still important to analyze the level of rootedness of M5S, especially in times of new political movements and personal party that emerged. In Italy there is strong evidence that preference voting allowed candidates to compete

\footnotetext{
${ }^{8}$ Electoral movements underlined an high level of change in voting behaviour (see Istituto Cattaneo of Bologna).

9 Mr. Casaleggio said that his company's software, platform and tools had played a key role in Five Star's changing of Italy. The other parties, he added, were "light years behind" while "we are at the crest of the wave".

${ }^{10}$ For the emergence, the kind of organization and political representation of M5S, see Lanzone (2015), Corbetta and Gualmini (2013) and Biorcio \& Natale (2013).
} 
with their party mates to be elected and high usages of preference voting were present mainly in local elections. ${ }^{11}$

The degree of local penetration of the party, the popularity and electability of individual candidates can be a good indicator to better understand the electoral and political performance of the M5S and its institutionalization in the Italian party system. $^{12}$

Recent studies on this topic show low preference using by the M5S voters in the eight chief-towns local elections in 2016 even if "the competition among councillor candidates appears quite significant in different geographical areas. This aspect represents an important indication in party rootedness with a growing number of candidates able to obtain personal votes" (Lanzone et al. 2016).

Generally, the candidates' profile are able to get more preferences than others is an activist coming from the Meet $\mathrm{Up},{ }^{13}$ well known in the local community due to his/her professional job or as a volunteer in social associations. He/She is young (35/ 45-years-old) with a higher education and at his/her first attempt to be elected. In this respect, Pizzarotti confirms this kind of profile who is able to take advantage of being an outsider from traditional politics and parties and representative of the "New" politics.

His administrative activity was positively recognized by the Association of Italian Mayors and also by the previous Italian Prime Minister, Matteo Renzi, and the governor of Emilia-Romagna, Stefano Bonaccini, in different political situation. ${ }^{14}$ But as soon as it has been willing to institutionalize its structure all the contradiction emerged between party on the ground and in public office.

Since Pizzarotti became Mayor of Parma he started being critic against Grillo and Casaleggio. Conflict emerged immediately after winning the election in 2012 because he was not able to stop the opening of the incinerator that in Pizzarotti's opinion it was not their decisions and consequently now it must be monitored for emissions closely.

The question of internal democracy has become evident in Autumn 2012 with the complain made by Giovanni Favia, a leading M5S politician in Emilia-Romagna on the absence of debate and the role played by Grillo and Casaleggio. ${ }^{15}$ In 2016 Pizzarotti also received a legal notice for the investigation about some nominees at the Regio Theatre in Parma. Pizzarotti received an automatic Casaleggio

\footnotetext{
11 Typically, only about $30 \%$ of Italian voters used any of their available preference votes. The Southern average is 50\% and the Northern one is between 10 and 20\% (Pasquino 1972). In the last European elections only $15 \%$ of preference voting has been expressed by Italian electorate. See www.cise.luiss.it (last seen: 31st May 2017).

12 See Panebianco (1982).

13 Meet up i.e., visitor to the blog were invited by Grillo to use his platform to organize themselves independently in local activist groups. That represents local level of participation and activism with a significant degree of civic and political involvement dealing with local issues. It combines an offline presence with an online one, in public squares thanks the use of Meet up. It is a permanent organization with a high degree of professionalization and a web marketing company embedded within its central committee.

14 See http://parma.repubblica.it/cronaca/2017/02/06/news/m5s_renzi_solidarieta_al_povero_sindaco_ pizzarotti_-157711496/ (last seen: 31 May 2017).

15 In order to evaluate the role of Casaleggio see: Casaleggio (2012).
} 
correspondence after it was revealed that Pizzarotti was under investigation for mishandling the appointment of the head of the city's opera house that it was later proved groundless. Nevertheless, the movement suspended him because he did not inform Grillo.

Pizzarotti went out of the M5S in October 2016 and prepared his strategy to compete for his second mandate in Parma municipality. He created the civic list labelled "Effetto Parma" (Parma Effect), followed by some other Grillo's opponents in Genova, Verona, Livorno and so on.

M5S was apparently worried about his movement affected by traditional party problems. Also other historical members of the M5S stressed their disappointment because the movement changed in something different, becoming another thing such as a movement acting like a more traditional party. "Elected members in the MoVimento's lists have to respect certain rules designed to ensure they act in compliance with the view of politics as a form of civil service and not as a career; a limited number of mandates; the self-reduction of salaries; the rejection of electoral reimbursements and of any kind of public funding; the obligation to submit themselves periodically to the judgment of the electors through votes on the web; and maximum transparency in dealings with citizens (Bordignon and Ceccarini 2013: 434-435).

Since the anti-establishment FiveStar Movement was in office it has been in danger of splitting and creating chaos within the ranks for those who criticised leader Beppe Grillo. At national level, calls for a separate parliamentary group, threats of resignations and expulsion took place through the vote on Grillo's blog in 2015. In that vote among M5S supporters, almost 30,000 voters supporting the expulsion because they were "no longer in sync with the movement" while just over 13,400 were opposed. Despite Grillo's call for their resignation, the dissidents initially refused to quit the movement, arguing that the M5S should be able to tolerate internal debate because "We are the movement of direct democracy and we cannot even say that something could have been done better". Several other M5S lawmakers took similar stands, defending their right to critique the movement when they wish-even if they do not agree with what these particular dissidents said.

The M5S, which selects its candidates and policies via online polls of supporters, ejected some parliamentarians and elected in local councils either for expressing dissent or for breaking a ban on appearing on television chat shows. At the moment the M5s is indeed in trouble in many of the cities where administrative elections will be held in June 2017. Grillo is trying to silence through his blog dissident voices without forgetting the many divisions surfacing at local level. As it happens in Grillo's hometown of Genoa where the leader for the first time intervened to disown the online vote that had crowned the local candidate for mayor (favoured by the base unlike Grillo's closest allies in Liguria) and called for all members in Italy, not only in Genoa, to ratify the choice of the second candidate, considered as closer to the leadership's line.

Nevertheless the M5S is gaining new electoral ground due to the mistakes of other parties, a government in trouble, and, especially, because voters are sensitive to the message of the movement: the fight against the privileges of lobbies and the powerful (politicians and journalists being the target), the income of citizenship promised to the poor, criticism against the Euro and the EU made of bureaucracy and technocrats. If it takes into considerations their political communication the 
M5S uses a simplification of languages and proposals in comparison with traditional parties with their complex world (Bordignon and Ceccarini 2013).

Moreover, the political space of the post-ideology stance, which allows to mix right and left ideas and values, strengthens the winning formula. Another important issue is the electoral law for the next national elections, which should be held in 2018. The parliamentary debate is still working with different proposal, but nobody is close to get the $40 \%$ which, based on the current electoral law, would grant the majority premium.

Being an anti-establishment movement that challenged and determined protest to the Italian party system as a whole and the successful decision to run alone and reject alliances has been its most important electoral support. But its path towards conquering the country's government makes the M5s renounce its dogmatic approach and seek support and alliances with all the anti-Renzi forces, which has already indicated to be available for discussions.

\section{Conclusions and Implications}

In this article we analyzed the organizational path completed by the Italian Five Star Movement in last 10 years. The new political force born in 2005 as a web experience, in 2009 it became a political party with initial local intents and strong protest intents. In 2013 it decided to participate for the first time in general (national/parliamentary) election and in 2014 it completed its process inside the representative institutions obtaining seats in European Parliament.

It is possible to consider the same party an example of "new populism" (Lanzone 2017) with some unprecedented characteristics. It proposes a strong people call against "old" parties and political elites in general, taking advantage of protest wave. However, the M5S is now part of all representative institutions (local/ regional/national and sub-national): it is precisely this quick process of institutionalization to cause a lot of consequences on its internal structure. In particular, the party has some problems between different levels.

To better analyze changes and adaptions inside the party founded by the comedian Beppe Grillo, in the previous sections we considered a specific case of "overpromising populism" (Mény and Surel 2000, 2001), that of Parma. In 2012 just in Parma the M5S obtained its first mayor in a chief town. This event produced a lot of consequences. Especially, it was able to change relationships between party leadership (central office), new public office and local branches of the party. In Parma the M5S tested its first experience with representative institutions and "power". In our analysis we underlined problems between the mayor Federico Pizzarotti and the leader Beppe Grillo. The same problems caused divisions inside the party and started factionalism. The aspect is now part of all party faces and levels. In particular, divisions are very strong in new town such as Rome and Turin, where the M5S obtained mayors in 2016.

The process of adaptions inside the M5S remains now in progress and so it is possible to better consider the effects in the future. At this stage it is possible to underline two main aspects: the first is strictly related to the relationship between different levels (especially between party leader and the heterogeneous and large 
public office). The second aspect is again linked with the internal structure, but it is related to the Web 2.0 and its role. At the beginning, Internet was an instrument of participation/mobilization across the time it has become a strong organizational means that is able to influence internal structure of the party. By the Web 2.0 the M5S remarks its populist role and the role of the leader, too. In the future it is possible to consider this aspect a crucial indicator in party cohesion and organization (Lanzone 2017).

\section{References}

Albertazzi, D., and D. McDonnell. 2015. Populists in power. London: Routledge.

Biorcio, R., and P. Natale. 2013. Politica a 5 Stelle. Milano: Feltrinelli.

Bordignon, F., and L. Ceccarini. 2013. Five stars as cricket. Beppe Grillo Shakes Italian Politics, South European Society and Politics 18 (4): 427-449.

Bordignon, F., L. Ceccarini, and I. Diamanti (eds.). 2015. Un salto nel voto. Ritratto politico dell'italia di oggi. Laterza: Roma-Bari.

Casaleggio, G. (2012) Ho scritto io le regole del MoVimento 5 stelle, Il Corriere della Sera, 30 May.

Calise, M. 2010. Il partito personale. I due corpi del leader. Roma-Bari: Laterza.

Corbetta, P. (2013). Un web populismo dal destino incerto. In Il partito di Grillo, eds., P. Corbetta \& E. Gualmini, 197-214. Bologna: Il Mulino

Corbetta, P., and E. Gualmini. 2013. Il partito di Grillo. Bologna: Il Mulino.

Incerti, M., and F. Pizzarotti. 2012. Cittadini a 5 stelle. La partecipazione in rete che vince sui partiti. Roma: Alberti editore.

Ivaldi, G., M.E. Lanzone, and D. Woods. 2017. Varieties of populism across a left-right spectrum: The case of the Front National, the Northern League, Podemos and Five Star Movement (M5S). Swiss Political Science Review, Special Issue.

Lanzone, M.E. 2014. The post-modern populism in Italy: The case of the Five Star Movement. In The many faces of populism: Current perspectives, research in political sociology, vol. 22, ed. D. Woods, and B. Wejnert, 53-78. Bingley: Emerald Press Group.

Lanzone, M.E. 2015. Il Movimento Cinque Stelle. Il popolo di Grillo dal web al Parlamento. Novi Ligure: Edizioni Epoké.

Lanzone, M.E. 2017. New populism. In Political populism: A handbook, eds. R. Heinisch, C. HoltzBacha \& O. Mazzoleni, Baden: Nomos.

Lanzone, M. E., Morini, M. and Scotto, A. 2016. Preference Voting in Local Elections: candidates (and voters) in the case of the Italian Five Star Movement. Paper presented at SISP Annual Conference, University of Milan.

Mény, Y., and Y. Surel. 2000. Par le peuple, pour le peuple. Paris: Librairie Arthème Fayard.

Mény, Y., and Y. Surel. 2001. Populismo e democrazia. Bologna: Il Mulino.

Mény, Y., and Y. Surel (eds.). 2002. Democracies and the populist challenge. London: Palgrave Macmillan.

Morini, M., and A. Fiorini. 2013. Il caso Parma: le primarie comunali e gli esiti elettorali. In Le primarie da vicino. Analisi e bilanci sulle primarie comunali in Italia, ed. A. Seddone, and M. Valbruzzi, 157-186. Edizioni Epokè: Novi Ligure.

Mudde, C. 1996. The paradox of the anti-party party. Insights from the extreme right. Party Politics 2 (2): $265-276$.

Mudde, C. 2000. The ideology of the extreme right. Manchester: Manchester University Press.

Panebianco, A. 1982. Modelli di partito: organizzazione e potere nei partiti politici. Bologna: Il Mulino.

Pasquino, G. 1972. Le radici del frazionalismo e il voto di preferenza. Rivista Italiana di Scienza Politica 2 (2): 353-368.

Pizzarotti, F. 2016. Una rivoluzione normale. Milano: Mondadori Electa.

Tarchi, M. 2014. Italia populista. Dal qualunquismo a Beppe Grillo. Bologna: Il Mulino. 
Maria Elisabetta Lanzone is a postdoctoral research fellow and teaching assistant at the University of Genova (DISPO). She is also member of ERMES Laboratory at the University of Nice-Sophia Antipolis. She received her PhD in Political Science from the University of Pavia. Between 2015 and 2017 she spent two periods as Visiting Scholar in France and Belgium. Her main research interests are European populism, party membership, and elections.

Mara Morini is Assistant Professor at the University of Genova (DISPO) where she teaches Political Science, Comparative Politics and Eastern Politics. Her fields of research are primaries, party organization, democratization in Eastern Europe, and Russian Politics. In 2017 she spent a period of visiting research in Germany (Berlin). 